\title{
The Legal Framework for Mobility of Human Resources within EU: A Romanian Fiscal Liability Approach
}

\author{
By Mihaela Tofan* \\ Ana Maria Bercu*
}

\begin{abstract}
The European integration widened the area of activity for Romanian organizations on the markets of other member states, in the context of free movement of services. This freedom is manifested through the ability to provide services in another state without the obligation of the provider to register or authorise a branch (subsidiary) under the national rules of the host state. Moreover, there are effects on regulation in matter of social security for workers, permission to travel, their right to temporary residences etc. The issues of tax liability, in terms of the state entitled to demand the contribution to social security schemes (state of origin or the actual host country), must be analysed from the perspective of preserving the rights granted to workers. The lack of precise national regulation in this respect determined a large and heterogenic interpretation of the possibilities permitted to the organizations. Different actions asked for a different fiscal treatment and, in the end, they generated very various tax liabilities. The situation developed in the last seven years since the accession and conducted to a controversy case-law experience. Romanian case-law solutions in these matters determined important changes in the legal framework. Still, the regulation in force is not entirely efficient, some further improvements being proposed, both at national and EU level.
\end{abstract}

Keywords: Human resources; EU mobility; Tax system.

\section{Introduction}

European Union, in its current form, has its beginnings in 1957 and presents itself as a market integration project, based on the idea of the four freedoms of movement of goods, services, capital and persons. The project was initially limited to economic policy and trade barriers among Member States were reduced gradually to achieve a common market. Strengthening fundamental freedoms was based on the idea of progressive extension of the market.

The foundation of the EU's institutional framework set a precise route of the road to union, which must offer citizens an area of freedom, security and justice, without internal frontiers in which the free movement of persons is ensured for establishing an internal market and promoting cohesion and economic solidarity, social and territorial cohesion.

\footnotetext{
* Associate Professor, University Alexandru Ioan Cuza, Iasi, Romania.

*Associate Professor, University Alexandru Ioan Cuza, Iasi, Romania.
} 
Although social policy initiatives have tried to correct market processes in terms of "positive integration", EU policy has focused primarily on establishing economic freedom of movement. This was manifested by placing in the forefront of market liberalization the "negative integration", which meant reducing trade barriers through deregulation ${ }^{1}$. The theme of transnational posting of workers in the context of the single market of the services appears on the European agenda in the 80s, in response to the EU's founding states competitive pressures from new integrated members, with low-cost labour ${ }^{2}$.

The geographical mobility of workers within the same organization, given the specific activity or business initiatives, expansion and openness to other local markets is a phenomenon involving specific elements of human resources mobility. Working on large projects, covering an extended geographical area, with a subsidiary relationship equals with developing a business under different regulations, where usual operations are designed in various typologies that mark the status of the employment relationship.

\section{Methodological Aproach}

Insuring the transnational workers mobility within EU demands answers at least three conflicts: the national and EU regulation; the principle of freedom to provide services and freedom of movement of people; the principle of competition in providing services on free market. These situations create disputes and dynamic developments in European labour relations' regulation. From this confrontation of ideas, laws and economic theories and concepts, challenges for academic research emerged.

The objective of this research paper is to understand the regulation for human resources in the EU area. The phenomenon of posting of workers is analysed and particularly its manifestation in Member States where there are large differences in salary levels. This analysis points out the Romanian perspective, a country low positioned on the scale of remuneration. The Romanian peripheral status offers a special framework for the phenomenon of posting, both from institutional perspective and empirical manifestation of labour relations. The aim of the research is to present the phenomenon in relation to the national environment of origin country, in order to complete and enrich knowledge.

European human resources mobility covers specific terminology elements for different Member States of the EU, which further extends the area of research. Reducing barriers to labour mobility within the EU opens opportunities for internationalization even for newly established organizations, creating the need for understanding mechanisms involving human resource management ${ }^{3}$. The information on EU human resources mobility is gathered using four channels: the academic resources (literature review), the internet

\footnotetext{
${ }^{1}$ Blanke (2008) at pp. 5-6.

${ }^{2}$ Cremers (2010).

${ }^{3}$ Brewster, Dickmann \& Sparrow (2008).
} 
and media resources, the normative resources (both on national and EU level) and the jurisprudence in the field.

\section{European Legal Framework for Human Resources Mobility}

Freedom is one of the fundamental values of the EU, together with respect for human dignity, democracy, equality, legality and respect for human rights. The free movement of goods and capital is fully functional and complete, but the free movement of persons and services still faces difficulties. The national particularities delayed the last stages of integration, referring to the large heterogeneity in terms of competitiveness and level of remuneration of labour. The challenge is the reconciliation of national interests and characteristics, to ensure the complete fundamental freedoms.

Going through different stages of construction of the EU integration of new members, the concept of social dumping raised a subject at the center of general attention in the time of globalization and human resources mobility. Any research on the functionality of the European common market touches the issue of low labour costs of newly integrated member, a threat both for the labour market in the founding states and in the newest members. By definition, social dumping is considered unfair advantage in international trade, resulting from differences in direct and indirect costs of labour, constituting a significant competitive advantage for enterprises ${ }^{4}$. In this context, in 1996 the Council and European Parliament adopted Directive 96/71/EC on the posting of workers to provide services, ensuring a hard core of rules on working conditions and remuneration for posted workers. This hard core is based on the law in force in the state of performing temporary provision of services, instead of the home/origin state. The Directive was transposed and implemented by Member States by the end of 1999 .

The introduction of institutional mechanisms is always justified by positive goals that they will bring faster and more efficiency. The legal framework for establishing minimum conditions and remuneration rights for workers has a noble motivation, enhancing the level of wage regulations. However, any intervention by the state or supra-state authority in natural social environment might have negative effects and it is considered secondary measure of intervention.

Posting transnational may take three forms determined by the employeremployee work relationship, having in common the existence of an employment relationship between employee and employer making the posting. The first form involves a worker carrying out activities for a limited period in another country than the country where his employer is registered. There must be a contract between the employer and the beneficiary of the services that operates in another EU country.

The second form involves a worker carrying out activities for a limited time at an establishment located in another country than that of origin of the

\footnotetext{
${ }^{4}$ Eurofound (2012).
} 
employer, or to a company belonging to a group of companies, located in another EU member state territory.

The third legal situation is a temporary employee for a limited time, in another state than that of the employer, provided by a temporary employment or placement agency.

The employee sent to work in another country than the origin country of the employer will benefit from working conditions established by the law of the country where the activity is done. This regulation establishes the maximum duration he works, working time and minimum rest period, the minimum length of annual paid holidays, minimum wages, including overtime compensation or payment conditions for making available to employees by temporary employment, health and safety at work, protective measures applicable for pregnant employees, those with children and young people, equality of treatment between men and women and other provisions on nondiscrimination.

Table 1. The Standards in Directive 96/71/EC and following Regulation

\begin{tabular}{|l|l|}
\hline \multicolumn{1}{|c|}{ Directive 96/71/EC } & \multicolumn{1}{c|}{ Implementing regulation } \\
\hline $\begin{array}{l}\text { Maximum work periods and minimum } \\
\text { rest periods }\end{array}$ & $\begin{array}{l}\text { Directive 2003/88/EC on certain aspects of the } \\
\text { organization of working time }\end{array}$ \\
\hline Minimum paid annual holidays & $\begin{array}{l}\text { Directive 2003/88/EC on certain aspects of the } \\
\text { organization of working time }\end{array}$ \\
\hline $\begin{array}{l}\text { The conditions for the provision of } \\
\text { workers by temporary employment } \\
\text { agencies }\end{array}$ & $\begin{array}{l}\text { Directive 2008/104/EC on temporary employment } \\
\text { agencies }\end{array}$ \\
\hline $\begin{array}{l}\text { Health, safety and hygiene at work } \\
\text { Safeguards on the conditions of work } \\
\text { and employment of pregnant women or } \\
\text { women who have recently given birth, } \\
\text { children and young people }\end{array}$ & $\begin{array}{l}\text { Directive 89/391/EEC, on the implementation of } \\
\text { measures to encourage improvements in the safety } \\
\text { and health of workers at work }\end{array}$ \\
$\begin{array}{l}\text { Directive 92/85/EEC, on the introduction of } \\
\text { and health at work of pregnant workers and } \\
\text { workers who have recently given birth or are } \\
\text { breastfeeding } \\
\text { Directive 94/33/EC on the protection of young } \\
\text { people at work }\end{array}$ \\
\hline $\begin{array}{l}\text { Equal treatment between men and } \\
\text { women and other provisions on non- } \\
\text { discrimination }\end{array}$ & $\begin{array}{l}\text { Directive 2006/54/EC implementing the principle } \\
\text { of equal opportunities and equal treatment of men } \\
\text { and women in matters of employment and } \\
\text { occupation } \\
\text { Directive 2000/78/EC establishing a general } \\
\text { framework for equal treatment in terms of } \\
\text { employment and employment } \\
\text { Directive 2000/43/EC implementing the principle } \\
\text { of equal treatment between persons irrespective of } \\
\text { racial or ethnic origin }\end{array}$ \\
\hline
\end{tabular}

Since the adoption of Directive 96/71/EC on the posting of workers to provide services, political interest was maintained continuously and the phenomenon has attracted numerous scientific debate, carried out in note relations, in legal and court decisions, or in papers on economic and industrial relations. The EU has created a package containing minimum social standards 
in labour relations, which Member States have transposed into national law. European legal mechanism on the transnational posting of workers do not provide a clear answer to the question whether there can be a single minimum wage, or rather a set of rules establishing minimum rates of pay in the event of a posted worker individually. Moreover, there is much confusion about the standards to be used for comparing wages actually paid by the service provider $^{5}$.

Directive 2006/123/EC on services in the internal market establishes that a company providing services in a Member State under national laws, may use labour transposing in another Member State, without fulfilling the administrative procedures for establishing representatives on its territory. Legislative process, which led to the adoption of the directive on services, generated a broad debate with three-disciplinary approach: economic, legal and political attempts to go beyond the image of the "Trojan horse" (used by the opponents) or of the "white knight" (the proponents of this regulation). Legal analysis shows that the introduction of country of origin rule brings a novelty compared to the previous regulation, paving the way for service providers across national borders ${ }^{6}$.

The Directive 2008/104/EC on temporary work agency aims to establishing a single framework for performing such activities in the EU. Social versus economic dispute finds a venue. In this context, there is concern that the practical manifestation of the provision of staff by temporary work agencies will lean more towards the institutional manifestation of the freedom of provision of services, at the expense of measures to ensure protection and working conditions for temporary workers ${ }^{7}$. One of the three expressions of the posting of workers in the EU is when a worker of a temporary employment agency is made available to a user from a Member State, other than that in which the operator is established.

Rhetorically, the question arises whether the de-structuring of the social systems of developed countries and long-term is an advantage for new Europe members. Competitive advantages based on cheap labour are considered ephemeral and a chance to a level of development similar to that available today in the old Europe, but they strongly affect western states ${ }^{8}$.

To harmonise the social security legislation in the Member States, the EU regulatory system chooses the rule of origin for temporary mobility of workers. Given that the regulation in force sets the priority of the home rule on the social standards applicable to posted workers, there is a contradiction between the two regulatory planes overlapping the same situation. Supporters of the applicability of the principle lex loci laboris blame the lack of political support for the application of this rule and for mobility of social insurance ${ }^{9}$.

\footnotetext{
${ }^{5}$ Van Hoek \& Houwerzijl (2011).

${ }^{6}$ Chang, Hand \& Pelkman (2010).

${ }^{7}$ Vosko (2009).

${ }^{8}$ Joerges (2008)

${ }^{9}$ Cremers (2010).
} 


\section{Romanian Legal Framework for Human Resourses Mobility within EU}

When Romania joined the EU (2007), updating the regulation on human resources mobility became necessary, as part of implementing the acquis communautaire. The Romanian Parliament adopted Law no. 344/2006 on the posting of workers in the transnational provision of services, transposing Directive 96/71/EC. Similar legislation exists in other EU countries and it is applied when an enterprise of Romania decides to provide services in that state and for a limited period of time it relocates its employees in that state.

The Romanian workers' movement was affected by restrictive measures imposed by some Member States (Germany, UK, and Ireland) and it was completed after the deadline for full liberalization of the labour market in the EU (2014).

In the EU context, Romanian legal system does not comply with the conditions for deliberately using "social dumping" or "wage dumps", according to the following arguments. First, Romanian government does not deliberately maintain a level of welfare and low wage levels with the intention of dumping. Secondly, differences in wage levels between EU states are real and substantial and posting of workers in the transnational provision of services without imposing lex loci laboris on minimum pay does not mean pay below the home state. Thirdly, there is not a general European standard minimum wage to oblige employers to comply with.

The term ,worker" requires a preliminary analysis, in the context of Romanian legislation. In Romania, there is no generally applicable definition for the concept worker and Labour Code, although organic law does not define it. The list of forms of labour contract in Romanian law responds to a complexity of social relations: the individual employment contract, the labour relation of civil servants, the military employment legal relationship, status of cooperative members, members of the legal relationship of employment in agricultural companies, special legal relationship of the judiciary, the legal status of dignitaries, diplomats legal relationship, legal relationship for clerical staff, legal relationship of employment for daily contract, work as a sanction in the benefit of the community, civil servants work, the employment of people working in families which ensures a guaranteed minimum income and work performed by persons serving a court sentence ${ }^{10}$.

The individual employment contract and employee status, as they are governed by the Labour Code, may have more atypical forms of legal expression, set exhaustively by law: individual employment contract, fixedterm employment contract, the individual part-time employment, individual employment contract apprenticeship contract and working at home contract.

Posting is a unilateral act of the employer and it represents a suspension of the individual employment contract at employer's initiative. It temporarily changes a part of the individual employment contract, respectively the employer person for a period of maximum one year. It is an essential change of the employment relationship.

${ }^{10}$ Ţiclea (2013) at pp. 7-11. 
In this point, it is important to emphasise that the current regulations in Romania has inherited the communist period vision, when the rational use of human resources and universal employer status of state represented a sufficient justification for moving temporarily (or even permanently) employed persons, wherever and however, at full employer disposal. Currently, such a legal possibility given to the employer cancels the fundamental principle of the consensus of employment contract and ignores the realities of a market based on free regulation of economic environment, in which the workforce is using its own identity in a space of diversity.

Temporary mobility of workers between the legal entities that have structural and functional connection may be carried out. There must be clear regulation of trilateral relations employer of origin - posted worker - host employer, ensuring worker protection and relational functionality of the entire system. It is the case of institutional framework for the activity of temporary agent employment or the employer's intention to terminate the contract for an unwanted worker (avoiding mandatory procedural rules on dismissal) or to hide employment relations (avoiding taxation). From the legal point of view, we find incompatibility between the previsions of the Labour Code concerning the assignment of the contract in a different legal system ${ }^{11}$. Also, the suspension of the individual employment contract with the employer in Romania that is posting, excludes the portability of social security benefits from the country of origin in the host country, since there is no employment relationship with the employer ${ }^{12}$.

Emergency Ordinance no. 56/2007 on the employment and deployment of foreigners in Romania (OUG 56/2007) brings two novelties: the definition of stranger (excluding the citizens of another EU member state or the EEA) and the explicit definition of worker technically circumscribed only to the provisions of the enactment ${ }^{13}$.

The legal regulation on the work of foreigners in Romania is changed from late November 2014 through the publication of Government Ordinance no. 25/2014.

${ }^{11}$ Ştefănescu \& Nicolau (2012).

${ }^{12}$ Irimia (2013)

${ }^{13}$ Ştefănescu \& Nicolau (2012). 
Table 2. Typology of Posting under Romanian Legislation

\begin{tabular}{|c|c|c|c|c|c|c|}
\hline & posting in Labour Code & $\begin{array}{c}\text { 1st posting in } \\
\text { G.O. no. } 25 / 2014\end{array}$ & $\begin{array}{c}\text { 2nd posting in } \\
\text { G.O. no. } 25 / 2014\end{array}$ & $\begin{array}{c}\text { 1st posting in } \\
\text { Law no.344 }\end{array}$ & $\begin{array}{c}\text { 2nd posting in Law } \\
\text { no.344 }\end{array}$ & $\begin{array}{l}\text { 3rd posting in } \\
\text { Law no.344 }\end{array}$ \\
\hline Temporary mobility & $\max .6$ months & max. 12 months & max. 12 months & $\begin{array}{l}\text { limited, but no } \\
\text { max. limit }\end{array}$ & $\begin{array}{l}\text { limited, but no max. } \\
\text { limit }\end{array}$ & $\begin{array}{l}\text { limited, but no } \\
\text { max. limit }\end{array}$ \\
\hline Geographical mobility & from RO to RO & out of RO to RO & out of RO to RO & out of RO to RO & out of RO to RO & out of RO to RO \\
\hline $\begin{array}{l}\text { Functional mobility } \\
\text { - wage } \\
\text { - working time }\end{array}$ & $\begin{array}{l}\text { wage and working time favorable for } \\
\text { employee } \\
\text { working time accordingly to the RO } \\
\text { legislation }\end{array}$ & $\begin{array}{l}\text { wage to insure } \\
\text { subsistence } \\
\text { + returning home } \\
\text { - working time } \\
\text { according to the } \\
\text { origin legislation }\end{array}$ & $\begin{array}{l}\text { wage to insure } \\
\text { subsistence }+ \\
\text { returning home } \\
\text { - working time } \\
\text { accordingly to the } \\
\text { RO legislation }\end{array}$ & $\begin{array}{l}\text { working time } \\
\text { accordingly to the } \\
\text { RO legislation }\end{array}$ & $\begin{array}{l}\text { working time } \\
\text { accordingly to the RO } \\
\text { legislation }\end{array}$ & $\begin{array}{l}\text { working time } \\
\text { accordingly to the } \\
\text { RO legislation }\end{array}$ \\
\hline Posting initiative & unilateral decision of the entity of origin & $\begin{array}{l}\text { according to the } \\
\text { origin legislation }\end{array}$ & $\begin{array}{l}\text { according to the } \\
\text { origin legislation }\end{array}$ & $\begin{array}{l}\text { according to the } \\
\text { origin legislation }\end{array}$ & $\begin{array}{l}\text { according to the origin } \\
\text { legislation }\end{array}$ & $\begin{array}{l}\text { accord between } \\
\text { entity of origin - } \\
\text { employee }\end{array}$ \\
\hline Posted employee & citizen from RO, UE and EEA & $\begin{array}{l}\text { citizen non RO, } \\
\text { UE and EEA }\end{array}$ & $\begin{array}{c}\text { citizen non RO, } \\
\text { UE and EEA }\end{array}$ & citizen & citizen & citizen \\
\hline entity of origin & legal entity and individuals from RO & $\begin{array}{l}\text { legal entity non } \\
\text { RO, EE and EEA }\end{array}$ & $\begin{array}{l}\text { legal entity non } \\
\text { RO, UE and SEE }\end{array}$ & $\begin{array}{l}\text { EU and EEA } \\
\text { companies }\end{array}$ & $\begin{array}{l}\text { EU and EEA } \\
\text { companies }\end{array}$ & $\begin{array}{c}\text { EU and EEA } \\
\text { temporary work } \\
\text { agency }\end{array}$ \\
\hline entity of destination & legal entity and individuals from RO & $\begin{array}{l}\text { the beneficiary } \\
\text { of service }\end{array}$ & legal entity RO & $\begin{array}{c}\text { the beneficiary } \\
\text { of service }\end{array}$ & $\begin{array}{l}\text { entity from a group of } \\
\text { enterprises }\end{array}$ & the beneficiary \\
\hline $\begin{array}{l}\text { Working relation of } \\
\text { posting employee with the } \\
\text { entity of origin and entity } \\
\text { of destination } \\
\text { - contract } \\
\text { - working control } \\
\text { - payment }\end{array}$ & $\begin{array}{l}\text { - suspended contract with the entity of } \\
\text { origin, active contract with the entity of } \\
\text { destination - - working control from the } \\
\text { entity of destination - - payment by the } \\
\text { entity of destination }\end{array}$ & $\begin{array}{l}\text { - contract with } \\
\text { the entity of } \\
\text { origin } \\
\text { - working control } \\
\text { from the entity of } \\
\text { origin } \\
\text { - payment from } \\
\text { the entity of origin }\end{array}$ & $\begin{array}{l}\text { - contract with the } \\
\text { entity of origin } \\
\text { - working control } \\
\text { from the entity of } \\
\text { destination } \\
\text { - payment from } \\
\text { the entity of } \\
\text { destination }\end{array}$ & $\begin{array}{l}\text { - contract with } \\
\text { the entity of } \\
\text { origin } \\
\text { - working control } \\
\text { from the entity of } \\
\text { origin } \\
\text { - payment from } \\
\text { the entity of origin }\end{array}$ & $\begin{array}{l}\text { - contract with the } \\
\text { entity of origin } \\
\text { - working control } \\
\text { from the entity of } \\
\text { destination } \\
\text { - payment from the } \\
\text { entity of } \\
\text { origin/destination }\end{array}$ & $\begin{array}{l}\text { - contract with } \\
\text { the entity of } \\
\text { origin } \\
\text { - working control } \\
\text { from the entity of } \\
\text { destination } \\
\text { - payment from } \\
\text { the entity of origin }\end{array}$ \\
\hline $\begin{array}{l}\text { Legal relationship entity } \\
\text { of origin / entity of } \\
\text { destination }\end{array}$ & no rules & $\begin{array}{l}\text { contract for } \\
\text { providing } \\
\text { services }\end{array}$ & $\begin{array}{l}\text { commercial } \\
\text { contract }\end{array}$ & $\begin{array}{l}\text { contract for } \\
\text { providing } \\
\text { services }\end{array}$ & civil agreement & $\begin{array}{l}\text { contract for } \\
\text { lending working } \\
\text { power }\end{array}$ \\
\hline
\end{tabular}




\section{Tax Implication of Human Resources Mobility}

Low competitiveness combined with cheaper labour force characterised employers in New Europe countries. The segregation of employers in the east by imposing economic barriers will block their integration into the common market of services, involving temporary relocation of staff or creating temptation to fraud.

In terms of mobility of posted workers based on the mechanism of "low wages at home" to "high wages in western host countries", advantages and disadvantages for each of the stakeholders were identified. These facets are sometimes placed in direct relationship to strengthen the construction of arguments in a certain direction.

New Member States benefit of the competitive advantage of low labour cost, but workers who earn less are disadvantaged because deployed workers must live in the host country. The same new Member States lose highly skilled workers who accept lower-level jobs in western countries. Motivation that compensates for expensive housing conditions in the host is noble, but reality shows that posted workers pay rather "the price pontoon Hilton"14. Changing national model for labour relations, which some states in northern Union have adopted in response to the influx of "low-cost workers" posted under the EU regulation, has not had the desired effect on the trend number of this type of mobility. Cremers tried modeling the posting of workers in the transnational provision of services, ranging from a normal mechanism and decent established long-term partnership to totally illegal practices, associated with the term mailbox used only for recruitment work. His research focused on "seeking cheap labour" in 12 EU Member States and identified four patterns of manifestation of the posting of workers to provide transnational services: genuine, perfectly legal, legal and forgery.

Analyzing various deployment models, described by Cremer's characteristics, a number of variables describing the posting of workers can be identified. Conceptualizing the 4 situations, he determined employer-provider features, characteristics of the posted worker, the employment relationship between the employer and the posted worker, features the provision of services, pay and working conditions while deployed, living conditions in the host country, the real cost the provider labour (Figure 5). In our opinion, it is important to distinguish the real posting, the posting according to the law in force, the posting in the spirit of the law and the posting beyond the law. The feature for each of them is presented below ${ }^{15}$.

\footnotetext{
${ }^{14}$ Cremers (2011).

${ }^{15}$ Tacu (2012).
} 
Tabel 3. Models of Actual Posting

\begin{tabular}{|c|c|c|c|c|}
\hline $\begin{array}{c}\text { model of } \\
\text { posting }\end{array}$ & real & $\begin{array}{l}\text { according to } \\
\text { the law in force }\end{array}$ & in the spirit of law & beyond the law \\
\hline the employer & $\begin{array}{l}\text { specialised } \\
\text { subcontractor }\end{array}$ & $\begin{array}{l}\text { the decision of } \\
\text { posting is based } \\
\text { on the cost of } \\
\text { work in the } \\
\text { destination state }\end{array}$ & $\begin{array}{l}\text { the decision of } \\
\text { posting is based on } \\
\text { the cost of work in } \\
\text { the destination state }\end{array}$ & $\begin{array}{l}\text { the employer has } \\
\text { only a P.O. box, not } \\
\text { a subsidiary in the } \\
\text { state of origin }\end{array}$ \\
\hline the employee & any profession & any profession & any profession & any profession \\
\hline $\begin{array}{l}\text { labour relation } \\
\text { between the } \\
\text { employer and } \\
\text { the employee }\end{array}$ & $\begin{array}{l}\text { working } \\
\text { contract }\end{array}$ & $\begin{array}{l}\text { any legal } \\
\text { contract for } \\
\text { using work }\end{array}$ & $\begin{array}{l}\text { any legal contract } \\
\text { for using work }\end{array}$ & $\begin{array}{l}\text { ex workers in the } \\
\text { destination state } \\
\text { who returned to the } \\
\text { origin state }\end{array}$ \\
\hline $\begin{array}{l}\text { the service } \\
\text { provided }\end{array}$ & $\begin{array}{l}\text { temporary } \\
\text { services }\end{array}$ & $\begin{array}{l}\text { any legal type of } \\
\text { activity }\end{array}$ & $\begin{array}{l}\text { the activity with } \\
\text { larger gap in } \\
\text { payment between } \\
\text { the origin and the } \\
\text { destination state }\end{array}$ & $\begin{array}{l}\text { hidden workers for } \\
\text { the destination state }\end{array}$ \\
\hline $\begin{array}{l}\text { working } \\
\text { conditions and } \\
\text { the wage }\end{array}$ & $\begin{array}{l}\text { good level of } \\
\text { payment } \\
\text { (acceptable for } \\
\text { the employees) }\end{array}$ & $\begin{array}{l}\text { - The difference } \\
\text { with basic social } \\
\text { standards is } \\
\text { small } \\
\text { - Can be } \\
\text { completed by } \\
\text { exceeding } \\
\text { normal working } \\
\text { time, poor } \\
\text { working } \\
\text { conditions }\end{array}$ & $\begin{array}{l}\text { - Deduction of tax } \\
\text { from wages } \\
\text { - Repay part of the } \\
\text { salary upon return } \\
\text { - Risks to health and } \\
\text { safety, fatigue, lack } \\
\text { of training, rules and } \\
\text { warnings of work } \\
\text { equipment failure, } \\
\text { poor working } \\
\text { environment }\end{array}$ & $\begin{array}{l}\text { - Unpaid overtime } \\
\text { (from } 40 \text { hours / } \\
\text { week } 60 \text { hours / } \\
\text { week) } \\
\text { - Lack the } \\
\text { minimum, and the } \\
\text { following rest } \\
\text { (day/week) }\end{array}$ \\
\hline $\begin{array}{l}\text { life condition } \\
\text { in the origin } \\
\text { state }\end{array}$ & $\begin{array}{l}\text { lower than the } \\
\text { state of } \\
\text { destination }\end{array}$ & $\begin{array}{l}\text { Can be filled } \\
\text { with improper } \\
\text { living } \\
\text { conditions }\end{array}$ & $\begin{array}{l}\text { - Loss of pay } \\
\text { administrative costs } \\
\text { for accommodation, } \\
\text { meals and transport } \\
\text { - Isolation of locals } \\
\text { and work colleagues }\end{array}$ & $\begin{array}{l}\text { - Living in "the } \\
\text { price of Hilton } \\
\text { pontoon" }\end{array}$ \\
\hline $\begin{array}{l}\text { the real cost for } \\
\text { working for the } \\
\text { provider of } \\
\text { services }\end{array}$ & not determined & $\begin{array}{l}\text { Lower social } \\
\text { contributions in } \\
\text { the State of } \\
\text { origin only if it } \\
\text { were paid by a } \\
\text { supplier to the } \\
\text { host }\end{array}$ & $\begin{array}{l}\text { - Wages does not } \\
\text { correspond to the } \\
\text { hours worked and } \\
\text { the level of } \\
\text { qualification } \\
\text { - Unlawful } \\
\text { deductions from } \\
\text { wages and repay } \\
\text { part of the salary } \\
\text { upon return } \\
\text { - Choosing the } \\
\text { "cheaper" collective } \\
\text { agreement or } \\
\text { negotiating } \\
\text { framework } \\
\text { - Loss of pay } \\
\text { administrative costs } \\
\text { for accommodation, } \\
\text { meals and transport }\end{array}$ & $\begin{array}{l}\text { - Counterfeited } \\
\text { certificates or } \\
\text { portable documents } \\
\text { - Tax documents } \\
\text { for the service } \\
\text { (invoices) that can } \\
\text { not be verified. }\end{array}$ \\
\hline
\end{tabular}


The attractiveness of a gain throws employer competitiveness in a race against time to ensure the posted worker ("low-expatriate") minimum wage requested by the host country regulation. The temptation to commit fraud, to neglect working conditions of workers and to abandon any human resource management activities to reduce costs, induces a behaviour that produces longterm consequences.

Also, the current regulation for posting permits tax avoidance in the benefit of employers, which has to be limited. A step was made in Romanian legislation, by adopting the regulation saying that all the payments made to the posted employees have the feature of a salary and must be treated in consequence.

\section{Concluding Remarks}

Temporary relocation across national boundaries will exist as long as human labour, and will produce maximum economical and social benefits only if institutional mechanisms that regulate it will be permanently updated.

The problems currently affecting the EU labour market are generated by competition between enterprises in different Member States markets and the relocation of companies in countries with low wages. Given the pay gap, especially between the old Member States and the newly integrated, the principle of freedom of movement of people leads to labour migration.

The gaps between Member States, manifested in economic development, the cultural pattern but also in social terms, are addressed through mutual recognition and subsidiary. The biggest challenge appears to be the reconciliation of economic freedom with national social models in the context of free movement of workers, without altering the substance of any of the two freedoms.

National legal rules aim to ensure the fulfillment of the fundamental objective of the EU, namely the abolition of obstacles to the free movement of persons. Promoting transnational provision of services requires fair competition for businesses in relation to the local providers and measures to guarantee the rights of workers. Understanding of human resources mobility regulation implies full knowledge of national and European institutional framework, of definitions and of mobility structure, in order to identify the direction for regulation improvement.

Comparing minimum social standards with EU minimum social standards, only minimum wage is not accompanied by a European legislative act. On that basis, the national laws of the 28 Member States, both those with high levels of pay and those with low levels of pay, aligned to social standards imposed. 


\section{References}

Blanke, T. (2008). 'Die Entscheidungen des EuGH' in den Fällen Viking, Laval und Rueffert - Domestizierung des Streikrechtsund europaweite Nivellierung der industriellen Beziehungen, Oldenburger Studien zur Europäisierung und zur transnationalen Regulierung, 18.

Brewster, C., Dickmann, M. \& P. Sparrow (2008). 'A European perspective on IHRM: an Introduction' in international human resource management: a European perspective (eds. M. Dickmann, Ch. Brewster \& P. Sparrow) - 2nd ed., Taylor \& Francis e-Library.

Chang, M., Hanf, D. \& J. Pelkmans (2010), 'The Services Directive: Trojan Horse or White Knight?' in Journal of European Integration Vol.32(1): 97-114

Cremers, J. (2010). 'Rules on working conditions in Europe: Subordinated to freedom of services?' in European Journal of Industrial Relations Vol.16(3): 293-306.

Cremers, J. (2011). 'In search of cheap labor in Europe. Working and living conditions of posted workers', in European Institute for Construction Labor Research (CLR) Studies 6.

Eurofound (2012). European industrial relations dictionary, online, European Foundation for the Improvement of Living and Working Conditions (Eurofound), http://www.eurofound.europa.eu/areas/industrialrelations/dictionary/index.htm

van Hoek, A. \& M. Houwerzijl (2011). 'Comparative study on the legal aspects of the posting of workers in the framework of the provision of services in the European Union'. European Commission (Contract Number VT/2009/0541).

Irimia, V. (2013). 'Detaşarea lucrătorilor în Uniunea Europeană - probleme şi soluţii practice', in Revista Română de Dreptul Muncii 1/2013: 41-46.

Joerges, C. (2008). 'A New Alliance of De-Legalisation and Legal Formalism? Reflections on Responses to the Social Deficit of The European Integration Project', in Law Critique Vol. 19: 235-253.

Ştefănescu, A. \& E. Nicolau (2012). 'Some considerations regarding the posting of the romanian workers to E.U. and Non - E.U. countries', in Journal of Legal Studies 1-2/2012: p. 225-234.

Tacu, C. (2012). 'Posting of Workers in Crisis: Europe Looking for Solutions', in University "OVIDIUS" Constanta Annals - economical science series, Vol. XII, no. 2/2012, ISSN: 1582 - 9383

Ţiclea, A. (2013). Tratat de Dreptul Muncii - Legislaţie. Doctrină. Jurisprudenţă Ediţia a VII-a revizuită şi adăugită, Universul Juridic, Bucureşti, 2013

Vosko, L.F. (2009). 'Less than adequate: regulating temporary agency work in the EU in the face of an internal market in services', in Cambridge Journal of Regions, Economy and Society, Vol. 2: 395-411. 